\title{
중 \\ CENTRE FOR \\ SOCIAL SCIENCE RESEARCH \\ Transnational mobilisation on access to medicines: The global movement around the imatinib mesylate case and its roots in the AIDS movement
}

Eduard Grebe and Marcus Low

CSSR Working Paper No. 349

December 2014

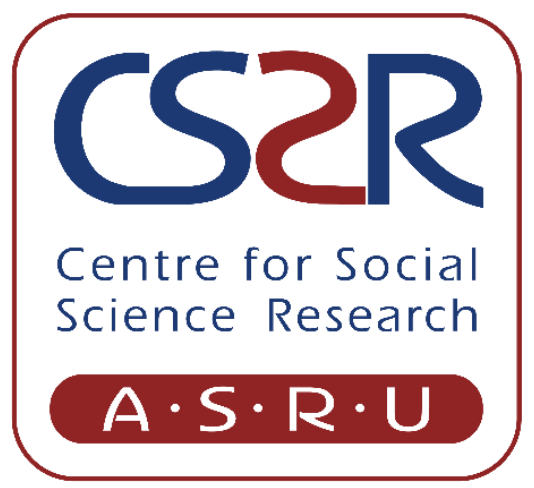




\title{
Published by the Centre for Social Science Research University of Cape Town 2014
}

http://www.cssr.uct.ac.za

This Working Paper can be downloaded from:

http://cssr.uct.ac.za/pub/wp/349/

ISBN 978-1-77011-336-7

(c) Centre for Social Science Research, UCT, 2014

\begin{abstract}
About the authors:
Eduard Grebe is based in the Centre for Social Science Research at the University of Cape Town. eduard.grebe@uct.ac.za (corresponding author).

Marcus Low works for the Treatment Action Campaign in Cape Town. marcus.low@tac.org.za.
\end{abstract}

Acknowledgements:

An earlier version of this paper was presented at the XVIII ISA World Congress of Sociology, Yokohama, Japan on 15 July 2014. The authors contributed equally to the conceptualisation, fieldwork for and writing of the paper. It benefited tremendously from comments and suggestions by Prof Nicoli Nattrass, and the authors wish to express their gratitude and debt to her. The authors further wish to thank the informants who gave of their valuable time to assist with this research. 


\section{Transnational mobilisation on access to medicines: The global movement around the imatinib mesylate case and its roots in the AIDS movement}

\section{Abstract}

Starting in 2006, a patent dispute emerged in India with significant implications for global access to medicine. An application by Novartis for a 'new formulation' patent on the beta crystalline form of the cancer drug imatinib mesylate was rejected. Novartis responded by challenging the legality of provisions designed to protect access to medicines in India's patent legislation. A global activist movement emerged in defence of these aspects of Indian patent legislation mainly because the challenge threatened access to medicine at a systemic level, given India's critical role as a supplier of generic medicines to developing countries. The mobilisation described in this paper exploited existing activist networks and broader 'networks of influence' built during prior campaigns conducted around access to antiretroviral drugs. AIDS activists consequently played a key role in the global mobilisation around the imatinib mesylate dispute, aimed at generating public outrage and political pressure against Novartis's challenge to Indian patent law. A critical 'broker' in these transnational networks is identified as the medical charity Médicins sans Frontières (MSF), and specifically its dedicated medicines access campaign, which linked disparate activist groups together, disseminated information and mobilised AIDS activists across the world in support of the Indian patent flexibilities. In 2013 the Indian Supreme Court upheld the relevant sections of the law, representing a significant victory for the international medicines access movement. This movement illustrates the power of transnational mobilisation to help bring about 'moral consensus' and to deploy influence and social power at the global level sufficient to overcome substantial corporate power. But we also argue that both the emergence of the 'global AIDS movement' and the emergence of a transnational social movement around the imatinib mesylate dispute depended on a set of historical circumstances that are unlikely to persist and that the broader medicines access movement therefore faces significant challenges to its sustainability and future success. 


\section{Introduction}

From 2005 to 2013 an extraordinary transnational movement was active against the patenting in India of the drug imatinib mesylate (specifically: a new 'beta crystalline' formulation of the drug). Imatinib mesylate is branded 'Glivec' and 'Gleevec' by the patent-holder in the US and elsewhere, the Swiss multinational Novartis, ${ }^{1}$ and is unusually effective in the treatment of chronic myeloid leukaemia.

In 1999 India had first amended its Patents Act to comply with its obligations as a member of the World Trade Organisation (WTO) (with later amendments following and final amendments in 2005). The new patent rules (including the final amendments, retroactively) took effect on 1 January 2005, but in the interim companies could use a 'mailbox' system which allowed for exclusive marketing rights to be granted and patent applications lodged from 199 to be evaluated from 2005. Imatinib mesylate had been available before 2005 and hence was not likely to be given a patent in India. In 2006, the Indian Patents Office refused Novartis's application for the beta crystalline form of imatinib mesylate - in part on the grounds that it did not meet the criteria set out in section 3(d) of the amended Patents Act which requires that new forms of known substances must exhibit enhanced efficacy to be patentable. The application was further subject to a 'patent opposition' filed on behalf of a cancer patients group. Novartis challenged both the Patents Office's decision to refuse patent protection and the validity of Section 3(d) itself in court. This, in turn, sparked an international response by health activists and professionals concerned that this could threaten the Indian generic medicines industry's continued ability to supply affordable medicines to developing countries across the world.

The medical charity Médicins sans Frontières (MSF), and specifically its dedicated medicines access campaign, acted as a critical 'broker' in the transnational networks that constituted the social movement in defence of medicines access, by linking disparate activist groups together-including groups focused on AIDS, cancer and other diseases. We will attempt to show that the pre-existing transnational AIDS medicines access movement provided resources, knowledge and 'bodies on the ground' in this new campaign, activated to a significant extent by MSF's ability to coordinate activism internationally. This transnational network, which was critical in the movement's eventual successes, was by no means an MSF creation, and has complex roots, but MSF's role was nevertheless critical bringing the imatinib

\footnotetext{
${ }^{1}$ In 2013 Novartis ranked first among pharmaceutical manufacturers in global sales (Novartis, 2013).
} 
mesylate patent dispute to the attention of AIDS and other medicines access activists across the world and coordinating their activism, as well as for a sophisticated 'public relations' campaign against Novartis's actions.

Militant international health activism (as it relates to access to medicines and the impact of intellectual property rights protection on the latter) has its roots in the AIDS epidemic and the global struggle for antiretroviral treatment. On the surface it seems strange that a substantial transnational movement emerged around the obscure legal points of a dispute over the patentability of a drug needed by relatively few patients for a disease much less visible than the HIV/AIDS pandemic had been. This paper explains why this seemingly unlikely movement emerged and ultimately helped defeat multinational corporate power with both the patent rejection and a progressive interpretation of the relevant provisions in the Indian Patents Act ultimately upheld by the Indian Supreme Court in 2013.

\section{Activism in support of access to medicines in the TRIPS-era}

The movements and 'repertoires of action' (activist tactics and methods) that emerged in response first to the AIDS crisis among North American gay men and later the global HIV/AIDS pandemic was probably the most significant health-focused social movement the world has seen. A key driver of the globalisation of AIDS activism was the fact that antiretroviral therapy was unavailable to the vast majority of those in need in the years following the 1996 discovery that HIV disease could be effectively treated with 3-drug regimens (known as Highly Active Antiretroviral Therapy or HAART).

When the AIDS epidemic first became visible among gay men in the United States in the early 1980s, community mobilisation was the primary form of care and support available to most patients. The gay community had been politicised by the struggles over equality (from the Stonewall era into the late 1970s and early 1980s). AIDS activism quickly emerged in which groups largely composed of gay men organised in order to pressurise the US government, research agencies, the drug regulatory body (the FDA) and the pharmaceutical industry, in order to ensure adequate funding for research, drug development and fast-tracked approvals of promising treatments (see Epstein, 1996).

In 1996 researchers announced the results of studies that showed the efficacy of HAART (in which a 'cocktail' of three drugs are given to suppress replication of HIV), the first truly effective treatment for AIDS. Although new antiretroviral 
drugs have been developed since then, triple-therapy antiretroviral treatment remains the standard of care today. The development of effective treatment meant that AIDS became a manageable condition as long as drugs could be procured. As a result, the focus of AIDS activism shifted away from drug research, development and regulatory approval to access to drugs, with the main barrier being the prices of these antiretroviral drugs. At the same time, as Smith and Siplon (2006) document, AIDS activism became increasingly globalised, as it was in developing countries, particularly Africa, that the vast majority of patients were located and the least resources were available to procure and offer treatment, thus making affordability of drugs a particularly acute challenge. The main impediment to large-scale international treatment provision was the unaffordable prices charged by multinational pharmaceutical corporations who had developed (often drawing on publicly-funded research) and marketed the drugs necessary for effective multidrug treatment regimens (Mrazek, 2002; Shadlen, 2004; Kapstein and Busby, 2013).

Activist groups emerged in countries like Brazil, Thailand and South Africa and formed links with North American and European activists to form a truly transnational AIDS treatment access movement (also see Grebe, 2011; 2012a; Kapstein and Busby 2013; Smith et al., 2013). These movements focused on the affordability of AIDS treatment.

The pricing policies of the pharmaceutical corporations were made possible by intellectual property rights (IPR) protection on pharmaceutical products, which - having long existed in the Global North—were being expanded across the Global South in the wake of the WTO-administered Agreement on TradeRelated Aspects of Intellectual Property Rights (TRIPS). TRIPS had been agreed in 1994 and required WTO members to implement patent protection in 'all fields of technology' (WTO, 1994). A transition period for developing countries expired in 2005-with further extensions for least developed countries (WTO, 2014). India's introduction of pharmaceutical patents in 2005 was the direct result of its obligations under TRIPS. Prior to TRIPS, countries had widely varying intellectual property regimes with respect to pharmaceutical products.

Developing countries were compelled to reform their patent laws to become TRIPS compliant at the same time that the scale of the HIV epidemic in SubSaharan Africa was becoming clear. TRIPS's interpretation was contested and authoritative precedents did not yet exist. Many countries facing serious healthcare challenges were struggling with the question of how to balance TRIPS compliance and the need for access to affordable medications. In South Africa, a set of amendments to the Medicines Act was challenged by a group of 
39 pharmaceutical companies in a case that became known as the $\mathrm{PMA}^{2}$ case of 2000. The reforms in South Africa attempted to provide some safeguards against the potentially harmful effects of providing longer periods of patent protection ${ }^{3}$ (including allowing for 'parallel importation' and generic substitution at the point of sale, etc.). The pharmaceutical companies eventually dropped the case early in 2001, following strong local and global mobilisation against their case, primarily by AIDS activists, and the prospect of patients sick with AIDS testifying in court. The case was widely perceived as a public relations disaster for the pharmaceutical industry.

The PMA case, together with strong leadership from the Brazilian government, strong activist mobilisation and a number of other factors laid the groundwork for the Doha Declaration of 2001 (Abbott and Reichmann, 2007; Kerry and Lee, 2007; Forman, 2008; Nunn et al., 2009), which clarified much of the legal uncertainty that had existed around the TRIPS agreement, particularly with regard to flexibility in domestic law designed to safeguard public health and affordability of drugs. In the declaration, WTO member countries state that:

'We affirm that the agreement [TRIPS] can and should be interpreted and implemented in a manner supportive of WTO members' right to protect public health and, in particular, promote access to medicines for all' (WTO, 2001).

The Doha Declaration constituted a major victory for the global AIDS treatment access movement, ${ }^{4}$ and provided a sufficiently flexible interpretation of the obligations of member states under TRIPS to allow the patent law reform in India to incorporate measures aimed at protecting access to medicine (much more flexible than in South Africa where the legal amendments required by TRIPS were made prior to the Doha Declaration). These flexibilities became the core issue in the imatinib mesylate dispute.

Global AIDS activist networks comprising Northern and Southern activists became extremely active on IPR-related barriers to access to medicine from the late 1990s, with remarkable success (see Smith and Siplon, 2006; Nattrass,

2 PMA refers to the Pharmaceutical Manufacturers of South Africa, a group mainly representing multinational pharmaceutical companies operating in South Africa. These were patent-holders on drugs rather than generic drug manufacturers.

${ }^{3}$ South Africa had allowed 16 years of patent protection on pharmaceutical products, but TRIPS compelled it to lengthen this period to 20 years.

${ }^{4}$ We frequently refer to 'the global AIDS movement' - a broader movement trying to secure an adequate response world-wide - and 'the global AIDS treatment access movement' more narrowly focused on treatment access. The movements overlap and cannot be rigorously distinguished. 
2008; Grebe, 2012a; Kapstein and Busby, 2013). It drew on a previouslyexisting, but extremely small and limited group of activists for technical expertise. ${ }^{5}$ Its success depended on its relatively unique features of fast and flexible network formation, technology-based information flows and its incorporation of a diverse set of actors who would not normally be associated with social movements (including scientists and clinicians, intergovernmental bureaucrats and diplomats, journalists and even technocrats, as well as political actors within states) in what can be conceptualised as 'transnational networks of influence' (Grebe, 2012a). ${ }^{6}$ In addition, the public health crisis that HIV/AIDS constituted, especially in Sub-Saharan Africa, created a unique set of historical circumstances within which such a movement could attract high levels of funding, public attention and exert significant influence. Anand Grover (leader of the Lawyers Collective - a key player in the imatinib mesylate dispute - and former UN Special Rapporteur on the Right to Health) says, "Objective conditions in the world at that time favoured some sort of deliberate collective action."7

The 2001 'Doha Declaration' formalised the interpretation of public-healthrelated flexibilities in TRIPS and prompted significant, sustained activist pressure on pharmaceutical companies and states. Following the declaration antiretroviral drugs were increasingly licenced for generic manufacturing and provided at substantial discounts to developing country governments and agencies responding to HIV/AIDS in the worst-hit regions. Without successful transnational organisation the remarkable progress that had been made in access to treatment would not have been possible (Nattrass, 2014). By 2012, 61\% of eligible patients in low- and middle-income countries, about 9.7 million people, were receiving treatment (UNAIDS, 2013:46).

\section{Indian patent law reform in the wake of TRIPS}

India is an important global supplier of generic drugs, especially for HIV (Waning et al., 2010; MSF, 2014). The development of this industry was made possible by the fact that between 1970 and 2005 pharmaceutical products could not be patented in India. However, in order to comply with TRIPS, the Indian Patents Act was amended in 1999-introducing a 'mailbox' system under which patent applications could be lodged for evaluation in 2005, and exclusive

\footnotetext{
${ }^{5}$ Interview, Ellen 't Hoen (27/06/2014).

${ }^{6}$ Similarly, Olesen (2014) has argued for an inclusive definition of 'transnational social movements' that would accommodate participants in networks not normally thought of as 'activists'.

${ }^{7}$ Interview, Anand Grover (24/06/2014).
} 
marketing rights issued in the interim - and several times more, including a crucial set of final amendments promulgated in 2005. India's amendments ensured that the granting of pharmaceutical patents would occur no earlier than the 2005 TRIPS deadline required, likely driven both by the commercial interests of its thriving domestic pharmaceutical industry and political commitment to affordable medicines. Poor countries throughout the world, including in Africa, relied on imported Indian generic medicines, leading to India becoming known as 'the pharmacy of the developing world'.

Aware of the global importance of the Indian generics industry, AIDS (and other health-oriented) activists lobbied Indian parliamentarians intensively during the parliamentary deliberations on the amendments. ${ }^{8}$ (The Indian generics industry of course also lobbied Parliament with their commercial interests in mind.) A key actor in the international campaign to influence the final amendments to the Indian Patents Law being deliberated in the Indian parliament during 2005 was MSF's 'Access Campaign', which had both local representation in India and coordinated global activities through its Geneva headquarters and its many country offices. Many activist groups were made aware of the process, its implications and connected to Indian activists by MSF. ${ }^{9}$

On December 17 2004, the World Health Organization sent a letter to the Indian minister of Health and Family Welfare noting that a number of WHO member countries had expressed their concern that in the future, generic antiretroviral drugs from India may no longer be available to them. Citing both the Doha Declaration and resolutions of the WHO's World Health Assembly, the letter went on to state:

'As India is the leader in the global supply of affordable antiretroviral drugs and other essential medicines, we hope that the Indian government will take the necessary steps to continue to account for the needs of the poorest nations that urgently need access to antiretrovirals, without adopting unnecessary restrictions that are not required under the TRIPS Agreement and that would impede access to medicines' (Kim, 2004).

This letter, signed by Jim Yong Kim (now president of the World Bank) was cited in its entirety in the 2013 Supreme Court judgement on the imatinib mesylate case. It was a highly significant intervention, given the moral and institutional authority of the WHO. It was further significant that a multilateral

\footnotetext{
${ }^{8}$ Interview, Leena Mengheney (10/07/2014).

9 Interviews, Anand Grover (24/06/2014), Ellen 't Hoen (27/06/2014), Michelle Childs (27/06/2014) and Leena Mengheney (10/07/2014).
} 
body such as the WHO defied United States interests in such an explicit way. We believe that this move may well have been made possible or even prompted by the global activism about the case which had contributed to an emerging 'moral consensus' around the issue. It is possible that Kim would have written this letter even in the absence of the international campaign, but to the extent that the WTO and similar bodies were being directly lobbied by activists, this may represent an example of how the 'transnational network of influence' incorporated intergovernmental organisations and exploited their power of moral suasion. (Note that these networks need not necessarily be 'dense' and are conceptualised in such a way that informal linkages and exchanges can contribute their formation and effects.) Kajal Bhardwaj-former Lawyers Collective lawyer and prominent medicines access activist in India and internationally—says:

'In 2005 there was a massive campaign to preserve India as the pharmacy of the developing world ... that was really a massive international campaign where you had the UN writing in, the WHO, every national organisation possible, I believe even the French government.

...

We had protests and letters from as far as Burkina Faso on this.' ${ }^{10}$

It is widely believed that the inclusion in the final amendments of Section 3(d)'s stricter patentability criteria resulted from this campaign. Section 3(d) prohibits the patenting of mere new formulations of known substances unless it results in an enhancement of the efficacy of the substance ${ }^{11}$ (what exactly 'enhanced efficacy' entails would later become a crucial point of contention in the Supreme Court challenge by Novartis to the clause's interpretation in lower courts). Section 3(d) reads:

'(d) the mere discovery of a new form of a known substance which does not result in the enhancement of the known efficacy of that substance or the mere discovery of any new property or new use for a known substance or of the mere use of a known process, machine or apparatus unless such known process results in a new product or employs at least one new reactant.

Explanation.-For the purposes of this clause, salts, esters, ethers, polymorphs, metabolites, pure form, particle size, isomers, mixtures

\footnotetext{
${ }^{10}$ Interview, Kajal Bhardwaj (26/06/2014).

${ }^{11}$ Grover points out that the Lawyers Collective advocated that all new uses not be patentable. The eventual decision to allow patents for new uses in cases where increased efficacy could be shown was a relatively late compromise. Interview, Anand Grover (24/06/2014).
} 
of isomers, complexes, combinations and other derivatives of a known substance shall be considered to be the same substance, unless they differ significantly in properties with regard to efficacy; ${ }^{12}$

The 2005 Indian amendments utilised the clarity and flexibility provided by the Doha Declaration and created an intellectual property legal framework that would allow for a high level of generic competition in pharmaceutical products while remaining TRIPS compliant. It probably represented the most progressive interpretation of TRIPS in a major medicine-producing country at the time. Most notably, this was achieved through Section 3(d) of the amended Indian Patents Act. It was therefore probably inevitable that it would be challenged or tested in court. The key legal test of the 2005 Indian amendments, and specifically Section 3(d), came in the form of the imatinib mesylate dispute and related legal cases. As described below, it was widely recognised that the case would have direct implications for the global medicines supply from India.

\section{The imatinib mesylate patent dispute}

The campaign against the granting of a patent and Novartis's challenge to Section 3(d) was primarily conducted by activists based in India, but received substantial support from the global AIDS movement and technical support from organisations like Médicins sans Frontières (MSF) — which had (and still has) a programme dedicated to medicines access - and Knowledge Ecology International (KEI, previously named Consumer Project on Technology), one of the most prominent international activist organisations on intellectual property rights issues.

The inclusion of Section 3(d) in the final amendments was highly significant: Anand Grover - a founder of the Lawyers Collective, who represented civil society in the patent opposition to imatinib mesylate - says about the imatinib mesylate dispute, "the case was $99 \%$ won around the amendments in 2005 , and particularly 3(d)." He goes on to point out that the advocacy/publicity post-2005 was primarily about preserving Section $3(\mathrm{~d}) .{ }^{13}$ Grover also says, "HIV patient networks saw it as an access issue ... They are the ones who would actually come out on the streets ... and that movement was led by MSF." He further notes that the Lawyers Collective specifically left public relations and mobilisation largely to MSF. ${ }^{14}$

\footnotetext{
${ }^{12}$ India, Patents (Amendment) Act, 2005.

${ }^{13}$ Interview, Anand Grover (24/06/2014).

${ }^{14}$ Interview, Anand Grover (24/06/2014).
} 
The dispute arose after Novartis's application for a patent on the formulation of imatinib mesylate in a new beta crystalline formulation under the 'mailbox' system was refused by the Indian Patents Office in January 2006-on several grounds, including Section 3(d) of the Patents Act. Novartis responded by challenging the decision in the Madras High Court and, in addition, challenged the constitutionality and TRIPS compliance of Section 3(d).

Three distinct legal processes can be identified. These are briefly summarised below, before the associated local and transnational mobilisation is described. The phases are: (1) the patent application and patent opposition filed by civil society; (2) the initial legal challenge to patent rejection and the challenge to Section 3(d); and (3) the Supreme Court case revolving around Section 3(d).

(1) The patent application and patent opposition filed by civil society: While Novartis filed for a patent on the beta crystalline form of imatinib mesylate in India in 1999 (under the so-called 'mailbox system'), the validity of the patent was only assessed after the 2005 amendments came into effect. Generic versions of imatinib were already on the market in India by the time the legal changes came into force in 2005. The Lawyers Collective, an Indian public interest legal organisation, filed a 'patent opposition' under the stricter patentability criteria of Section 3(d) of the Patents Act on behalf of an Indian NGO, the Cancer Patients Aid Association (CPAA). Indian manufacturers of generic medicines also filed oppositions to Novartis's patent application. The patent application was rejected by the Indian Patents Office, as explained above.

(2) The initial legal challenge to the patent rejection and a direct challenge to Section 3(d): Following the rejection of the patent application in January 2006, Novartis challenged the rejection before the Madras High Court. The court referred the matter of the patent itself to the Intellectual Property Appellate Board (IPAB), which upheld the rejection in June 2009 on the grounds that the drug was a new form of an existing substance and was not shown to provide superior efficacy (in other words this rejection was squarely based on Section 3(d) of the amended Patents Act). ${ }^{15}$

Novartis also argued before the Madras High Court that Section 3(d) itself was not in line with the Indian Constitution and fell outside the scope of what was

\footnotetext{
${ }^{15}$ Intellectual Property Appellate Board. M.P. Nos 1 to 5/2007 in TA/1 to 5/2007/PT/CH; M.P.No.33/2008 IN TA/1/2007/PT/CH; TA/1 TO 5/2007/ PT/CH. 26 June 2009. Available at: https://www.scribd.com/doc/133340456/IPAB-Order-Dated-26-Jun-2009-in-Novartis-vUnion-of-India.
} 
permitted under the TRIPS agreement. In August 2007 the court rejected both these arguments. ${ }^{16}$

(3) The Supreme Court case: In response to the 2009 dismissal of Novartis's appeal by IPAB, Novartis petitioned the Supreme Court of India in August 2009, essentially arguing that Section 3(d) was incorrectly interpreted by the IPAB and that the drug was both novel and had 'increased efficacy'. Novartis argued that 'increased bioavailability' met the criterion of 'increased efficacy'.

Crucially, the court disagreed with Novartis and interpreted 'increased efficacy' to mean 'increased therapeutic efficacy'. Novartis had not shown that the beta crystalline form of imatinib mesylate had any 'increased therapeutic efficacy' over earlier forms of imatinib mesylate. The rejection of the patent and the validity of a strict interpretation of Section 3(d) were accordingly both upheld in the Supreme Court's April 2013 ruling:

'Therefore, in the case of a medicine that claims to cure a disease, the test of efficacy can only be "therapeutic efficacy".

... just increased bioavailability [which had been demonstrated] alone may not lead to an enhancement of therapeutic efficacy. Whether or not an increase in bioavailability leads to an enhancement of therapeutic efficacy in any given case must be specifically claimed and established by research data. In this case there is absolutely nothing on this score apart from the adroit submissions of the counsel.

...it must be held that on the basis of the materials brought before this Court, the subject product, that is, the beta crystalline form of Imatinib Mesylate, fails the test of section 3(d)...

In view of the findings that the patent product, the beta crystalline form of Imatinib Mesylate, fails in both the tests of invention and patentability as provided under clauses (j), (ja) of section 2(1) and section 3(d) respectively, the appeals filed by Novartis AG fail and are dismissed with cost. ${ }^{, 17}$

\footnotetext{
${ }^{16}$ High Court of Judicature at Madras. Novartis AG v. Union of India (UoI) and Ors.; Novartis India Ltd. v. UoI \& Ors. W.P. Nos.24759 and 24760 of 2006. 6 August 2007. Available at: $\underline{\mathrm{http}}$ ://judis.nic.in/judis_chennai/qrydispfree.aspx?filename=11121.

${ }^{17}$ Supreme Court of India. Novartis AG v. Union of India (UoI) and Ors.; Natco Pharma Ltd. v. UoI \& Ors.; M/S Cancer Patients Aid Association v. UoI \& Ors. Civil Appeal No. 27062716 of 2013. 1 April 2013. Available at: http://judis.nic.in/supremecourt/imgs1.aspx?filename=40212.
} 
The Supreme Court therefore ruled against Novartis partly on the basis that section 3(d) precludes patentability of new formulations unless substantive evidence of enhanced therapeutic efficacy can be demonstrated. The principle of strict patentability criteria in the case of new uses and new formulations was therefore upheld - a key objective of the international campaign.

Throughout these complex legal machinations, Indian and international health activists mobilised in support of the patent rejection and against Novartis's challenge of Section 3(d). These health activists included a newly militant cancer group, and much of the existing local and international network of AIDS drug access activists. During this period the strategies and 'repertoires of action' developed during the global struggle for access to ART (i.e. the institutional memory embedded in the global AIDS movement) were critical success factors as was the pre-existing activist networks formed during struggles over AIDS drugs. We draw largely on key informant interviews conducted with a selection of important actors in the struggle described here as well as documents and secondary literature.

The analysis presented in the next sections suggests that both the successes recorded by the AIDS treatment access movement in the late 1990s and early 2000s and, more recently, by the fledgling movement for access to medicines for other diseases (including non-communicable diseases, of which the imatinib mesylate dispute is perhaps the most significant example to date), were contingent upon a very specific set of historical circumstances and the deployment of a highly effective 'transnational network of influence'. Without the pre-existing AIDS movement, the struggle over imatinib mesylate would likely not have attracted as much international public attention nor have seen such high levels of mobilisation. Its status as the first important test case of TRIPS flexibilities embedded in Indian law (and India's status as 'pharmacy of the developing world') provided an incentive to AIDS activists across the globe to mobilise around the case.

\section{A global movement emerges and a 'moral consensus' starts to form in opposition to Novartis's challenge to Section 3(d)}

As explained above, the imatinib mesylate case (also referred to as the Novartis case), is in reality a number of related cases that came before Indian courts and tribunals over a period of seven years following the final amendment of India's Patents Act in 2005. The three central players in the legal and solidarity mobilisation story emerge as the Lawyers Collective, the CPAA and MSF, 
although a very wide range of activist groups, both within India and globally, were mobilised around the imatinib mesylate case.

The Lawyers Collective was founded in 1981, among others by Anand Grover, who still leads the organisation. It has been active on medicines access, specifically for HIV/AIDS for many years. Grover reports that the Lawyers Collective was first alerted to imatinib mesylate as an access issue by South Korean cancer activists, who were campaigning against Novartis's pricing of the drug in that country. ${ }^{18}$ James Love of KEI reports also being approached by South Korean cancer groups prior to the Novartis case. KEI had in fact conducted some analysis of the Research and Development (R\&D) costs of the drug, which were being used by Novartis to justify its price. ${ }^{19}$ KEI had played an important role in the global AIDS treatment access movement, particularly in providing technical assistance on medicines R\&D costing to AIDS groups, including to the Treatment Action Campaign during the PMA case in South Africa and a later 'excessive pricing' complaint against GlaxoSmithKline and Boehringer Ingelheim in terms of South African competition law (see SECION27, 1998; KEI, 2014). It later became involved in the imatinib mesylate case in India, providing analyses which the Lawyers Collective made extensive use of.

Imatinib mesylate had been introduced in the United States as Gleevec in 2003 at a price of US\$2,600 per patient per month. It was not on the Lawyers Collective's radar at the time since it did not represent an immediate access problem in India, where generic versions were available not long after the US launch at under $\$ 200$ per month (MSF, 2012). But upon being alerted to the drug's high price in markets like the US and South Korea, where it had patent protection, it realised both the threat that generic versions would become unavailable in India if the patent were approved and, upon analysis, saw that it was a relatively 'easy' target for a patent opposition since the application was for the 'new' beta crystalline mesylate form and it therefore clearly fell within the provisions of Section 3(d). ${ }^{20}$

\footnotetext{
${ }^{18}$ Interview, Anand Grover (24/06/2014).

19 Interview, James Love (26/06/2014). In South Korea, The Committee For Chronic Leukemia Patients and The Joint Committee For Solving the Glivec Problem and Improving Public Health Care making submissions to the National Human Rights Committee in 2002 (BASE21, 2002), calling for compulsory licences (IPLeft, 2003) and issuing calls for international solidarity (People's Health Coalition for Equitable Society, 2001). At one point Glivec became unavailable during a pricing dispute between Novartis and the South Korean government (People's Health Coalition for Equitable Society, 2001).

${ }^{20}$ Interview, Anand Grover (24/06/2014).
} 
As lawyers, they needed a client to represent (without which they could not directly attack multinational pharmaceutical interests on public interest grounds), but were also very aware of having a support and advocacy network available, should a test case arise. Grover says:

'We [India] had to fully comply with Trips by $1^{\text {st }}$ January $2005 .{ }^{21}$ So in 2001 we decided in the Lawyers Collective that it was very important that community organisations - and here I want to make a distinction between community organisations and civil society generally, like NGOs (those who are not directly affected like MSF or Lawyers Collective vs., say, positive people's networks). So we started in 2001 to educate the community networks around the country about patents. We found the response was not very good. ... But within a year or two we received requests from the community to continue educating and empowering the networks. Because the Lawyers Collective believes very strongly in community networks. ...

So by the time we started the [patent] oppositions in $2005 \ldots$ the first opposition was in fact the Glivec case, and we filed it on behalf of the Cancer Patients Aid Association, which is a service provider. But we had broadened our reach to not only HIV-positive networks but all socalled patients' groups ... [for] any sort of ailment. ${ }^{22}$

Grover is highly complimentary about the CPAA's willingness to take on, and make enemies of, a multinational pharmaceutical company (part of so-called 'Big Pharma'), especially in the light of cancer patients groups' general unwillingness to antagonise pharmaceutical companies. Cancer groups are generally perceived as non-hostile to pharmaceutical companies because the latter are the main funders of the former, and because it might threaten donation programmes, which is often the only way poor patients are able to access cancer treatment. ${ }^{23}$ For example, Tomlinson (2012) describes how the South African Cancer Alliance (a group of cancer patients' groups) actively distanced themselves from a Treatment Action Campaign-organised march in solidarity with the CPAA's imatinib mesylate case in India. ${ }^{24}$ When asked why the CPAA is more independent of pharmaceutical companies than other cancer groups, Leena Menghaney (who was working for MSF's India office on medicines

\footnotetext{
${ }^{21}$ The final amendments to the Act were only made later in 2005, but retrospectively active from 1 January.

${ }^{22}$ Interview, Anand Grover (24/06/2014).

${ }^{23}$ Interview, Kajal Bhardwaj 26/06/2014).

${ }^{24}$ A number of informants also made this point about cancer groups' general unwillingness to alienate pharmaceutical companies by questioning their pricing policies or otherwise criticise them.
} 
access at the time and had previously been with the Lawyers Collective), explains it largely in terms of individual agency. She specifically credits Y.K. Sapru, founder-chairman and CEO of the CPAA:

'The person who led the CPAA had worked with ... Big Pharma before, so he knew all their games. He was in some ways very astute politically. He very cleverly decided to use the imatinib mesylate case to fight the access battle. He was able to distinguish something that the HIV movement had early on had a discussion and resolution on: "we will not take pharma support, we will not take pharma money, we will return all this money they are trying to give us". I think that happened with CPAA. Despite lucrative offers and threats from Novartis, they refused to back down. ${ }^{25}$

Bhardwaj confirms:

'With cancer groups it is very hard to get them to come out [because the patients are ill]. ... Having said that, there was definitely a difference between the CPAA and other cancer groups. ... the head of the CPAA would go to meetings where he would be accused of biting the hand that feeds you. ${ }^{26}$

The wide and explicit refusal by AIDS activist groups to accept funding from pharmaceutical companies is one of the ways in which the AIDS treatment access movement had been exceptional. Patients' groups have traditionally been (and for the most part still are) rather quiescent, throughout the world. AIDS groups are the exception: in the South they had been politicised by an almost complete lack of access to treatment, and in the North by their rootedness in the political traditions of the gay rights movement as well as solidarity with Southern AIDS groups.

The Lawyers Collective had long been working in the area of medicines access, and had identified opposing patent applications as a strategic objective in its public interest legal work. So its involvement in a patent opposition under Section 3(d) was no accident, although the specific drug chosen was in a sense coincidental. In representing the CPAA, it handled legal aspects of the dispute throughout the legal processes. However, it deliberately adopted a 'hands-off' approach to the advocacy and activism surrounding the case, feeling that its position as the legal representative of the litigants required it to be seen as

\footnotetext{
${ }^{25}$ Interview, Leena Mengheney (08/07/2014).

${ }^{26}$ Interview, Kajal Bhardwaj (26/06/2014).
} 
relatively non-political. ${ }^{27}$ It did, however, recognise the importance of the political mobilisation. Much like the Treatment Action Campaign and its legal representatives in the AIDS Law Project (later SECTION27) in South Africa, it saw legal action and political mobilisation as complementary, recognising that the battle in the 'court of public opinion,' 28 including the likelihood that multinational pharmaceutical companies and Northern governments would lobby the Indian government, may influence the outcome of the case. Nevertheless, it left active political mobilisation to civil society partners.

Among these partners were the Indian Network for People living with HIV/AIDS (INP+) and a number of other Indian AIDS groups, as well as MSF, who coordinated much of the international solidarity campaign through both its India office and its global Access Campaign office in Geneva. Keck and Sikkink (1998) describe the structure and efficacy of transnational advocacy networks. Such networks were crucial in the AIDS medicines struggles, and it was precisely these existing networks that MSF leveraged for the case. It is notable that MSF is primarily a humanitarian medical organisation, and its Access Campaign grew out of its own need to access affordable medicines for treatment programmes it was conducting in developing countries. For example, its South African antiretroviral treatment project in Khayelitsha (set up in partnership with the Western Cape provincial government several years before HAART became widely available in that country) worked very closely with the Treatment Action Campaign and actively infringed patents on antiretroviral drugs in order to treat more patients with the available resources. Similarly, MSF had civil society and activist partners in many countries where it worked. Ellen 't Hoen, who was leading MSF's Access Campaign at the time, does point out, however, that it was a challenge to direct resources towards a cancer drug:

'It was very difficult for MSF to get involved with cancer drugs because MSF was not really involved in cancer treatment, and MSF is always very restricted to be vocal about or get involved with diseases with which they themselves, as a medical organisation, do not have experience. ${ }^{29}$

MSF already had an established India office and, even before the imatinib mesylate patent opposition was filed, had been coordinating international and local lobbying efforts to influence the final amendments to the Patents Act. The links between the Lawyers Collective and MSF were strong, Grover, in

\footnotetext{
${ }^{27}$ Interview, Anand Grover (24/06/2014).

${ }^{28}$ See Grebe (2011) for a discussion of this aspect in the South African context.

${ }^{29}$ Interview, Ellen 't Hoen (27/06/2014).
} 
emphasising this link, noted that Leena Menghaney had been working for the Lawyers Collective before joining MSF's India office. ${ }^{30}$

Informants report that it was not difficult for AIDS activists to see the relevance of the imatinib mesylate case, in particular the challenge to Section 3(d), to their own struggles. MSF was in many ways at the centre of an established transnational network of AIDS treatment access activists, and had strong links with the small, but extremely significant, community of technical experts within the broader medicines access community. These experts included people within MSF's own Access Campaign and KEI, but also in some others like South Africa's SECTION27. Bhardwaj confirms, "There is clearly a core group, or a [small] number of people, who are identifiable, who work on [technical aspects of intellectual property rights and medicines access]..."31

AIDS groups throughout the world, but perhaps most notably in India, South Africa, Thailand and Brazil, also already had within their ranks a cadre of activists well-versed in the challenge TRIPS and intellectual property rights protection posed to access to medicines. It is therefore not surprising that AIDS activists provided the bulk of activism in support of the patent rejection and against Novartis's various challenges to it and the court cases challenging Section 3(d) (and a progressive interpretation thereof), nor that MSF coordinated much of this activism. In spite of the difficulty mentioned earlier, then, the fact that Novartis was challenging a provision of Indian law of relevance for the entire supply of generic medicines to the developing world spurred into action both MSF's Access Campaign and the wider AIDS treatment and access to medicines movements. Ellen 't Hoen says: "If Novartis had only stuck to strictly challenging the decision of the patent controller it would have been more difficult for MSF to get involved" and also "This was the South African court case all over again." 32

Michelle Childs, who was a senior official in MSF's Access Campaign during the imatinib mesylate dispute, explains that the challenge to 3(d) "really helped centralise the idea of India as the pharmacy of the developing world." ${ }^{33}$ She further explains that the various legal cases we identified above "helped activists across the world realise that the legal provisions could be really important." ${ }^{34}$ In a sense, therefore, the imatinib mesylate dispute-especially the challenge to 3(d) - became a rallying point that made it possible to exploit and strengthen existing networks, but also pulled new participants into the network. Childs

\footnotetext{
${ }^{30}$ Interview, Anand Grover (24/06/2014).

${ }^{31}$ Interview, Kajal Bhardwaj (26/06/2014).

${ }^{32}$ Interview, Ellen 't Hoen (27/06/2014).

${ }^{33}$ Interview, Michelle Childs (27/06/2014)

${ }^{34}$ Interview, Michelle Childs (27/06/2014).
} 
describes how significant efforts and resources were expended on disseminating information about the imatinib mesylate dispute and its significance, including through the organisation of countless workshops and meetings with AIDS and health activist groups across the world, as well as translation of technical and legal information into digestible form aimed at non-expert activist audiences. Anand Grover points to the access of the Indian actors to a global network of AIDS activists as something of great significance. These were largely facilitated by MSF. Grover says, "We had an international fraternity. (...) We'd give out a call and groups like TAC [and others] would respond." 35

In December 2006 MSF launched a 'Drop the Case' campaign — which called on Novartis to drop their two court actions before the Madras High Court. According to MSF the 'Drop the Case' petition was signed by 450000 peopleincluding archbishop Desmond Tutu. Even though Novartis did not drop the case, the campaign likely played an important role in increasing public awareness of the case. It should be noted that this campaign was never truly aimed at persuading Novartis to withdraw its court action, but rather at influencing public opinion. Ellen 't Hoen says, "I was glad that Novartis didn't drop the case, and am extremely glad that [after they lost the case] this jurisprudence now exists." 36

To summarise: AIDS activism provided a critical resource for the successful mobilisation around imatinib mesylate. First, AIDS activists mobilised around a cancer drug, because existing networks facilitated wide understanding of the case's significance, particularly in the light of the challenge to Section 3(d). Second, the existence of well-developed AIDS-related activist networks provided an 'infrastructure for mobilisation' that could be rapidly activated to provide resources for the channelling of information, influence and social power (in what we term 'transnational networks of influence' since they stretch wider than networks only of activists, see Grebe, 2011; 2012a). Third, the 'repertoires of action' embedded in the institutional memory of the global AIDS movement provided inspiration for the mobilisation around the imatinib mesylate dispute (see below).

In part because of the work of MSF and others and the court proceedings in India, the imatinib mesylate case reignited international public debate about the potential of intellectual property protection to restrict access to medicines - and therefore an emergent 'moral consensus' that patent protection enabling the unaffordable pricing of life-saving drugs was unacceptable. In August 2007, Dr Brian Druker, one of the key researchers involved in the discovery of imatinib

\footnotetext{
${ }^{35}$ Interview, Anand Grover (24/06/2014).

${ }^{36}$ Interview, Ellen 't Hoen (27/06/2014).
} 
mesylate, wrote an open letter in which he questioned the way in which patents were blocking access to the drug:

'... the price at which imatinib has been offered for sale by Novartis around the world has caused me considerable discomfort. Pharmaceutical companies that have invested in the development of medicines should achieve a return on their investments. But this does not mean the abuse of these exclusive rights by excessive prices and seeking patents over minor changes to extend monopoly prices. This goes against the spirit of the patent system and is not justified given the vital investments made by the public sector over decades that make the discovery of these medicines possible' (Druker, 2007).

It was significant (and reminiscent of the period during which access struggles over AIDS drugs were being pursued) that this kind of comment appeared in major newspapers and international forums. The claims of the access to medicines movement-revolving around the central moral assertion that the need for access to medicines and the suffering of patients who are denied access overrides the well-established property rights of patent-holders (and perhaps that medicines as a life-saving commodity in a certain sense represents a public good) - are fairly radical and challenge the interests of a massive and influential industry in the Global North (see Smith and Siplon, 2006; Nunn et al., 2009; 't Hoen et al., 2011; Kapstein and Busby, 2013).

It is therefore not simply a question of directly contesting corporate power, but of a symbolic struggle in which the main objective is to generate a public sense of moral outrage. Actual street protests and other tactics of political contestation were more important for their symbolic impact in a 'public relations war' and in generating public attention and winning public support for the moral claims. 'Framing processes' (often taking the form of framing claims in terms of fundamental human rights) and the idea that 'new social movements' tend to pursue consensus around ideas and norms that go beyond a simplistic economistic notion of their 'interests' (see Keck and Sikkink, 1998; Taylor, 2004) are by no means new in the social movement literature. Nevertheless, we find it useful to refer to these general processes and the specific forms it took in the AIDS and medicines access movements collectively as the 'politics of moral consensus' (see Grebe, 2011; 2012a).

In a New York Times editorial published three days after the Supreme Court judgement, the paper argued that "The ruling is important ... because it establishes a limited precedent that requires drug companies to show real improvements in efficacy before they can get patent protection on updates to existing drugs in India" (NYT, 2013). The editorial also rejected Novartis's 
argument that such a ruling would decrease the incentive to invest in research and development of new medicines. Notably, it concluded with the comment that the ruling could "help poor patients get drugs at prices they can afford while preserving an incentive for true innovation" (NYT, 2013).

The types of activist actions undertaken both within India, and internationally in response to MSF's calls to action show striking similarities to the activities undertaken by AIDS activists during earlier campaigns over access to antiretroviral and other drugs for AIDS patients (note that these respective actions often involved many of the same people). During court proceedings, activists would demonstrate outside court, just like TAC demonstrated outside court during the PMA case and their later case in the South African courts that compelled the government to provide antiretroviral drugs for the prevention of mother-to-child transmission of HIV (see Grebe, 2011). Global days of action would result in (joint and separate) actions by AIDS groups across the world. As an example of how taking court action on behalf of patients, demonstrating outside court and mobilising local and global solidarity had been used in the AIDS movement and became part of its 'repertoire of action' is provided by TAC's mobilisation during the PMA case. This joint statement issued on 6 March 2001 is representative of the model of mobilisation widely used during these struggles:

'National and international organizations today welcomed the South African High Court's decision to accept evidence from the Treatment Action Campaign (TAC), which represents people living with HIV. ... TAC will give evidence about how brand name medicines are unaffordable for millions of people living with HIV in South Africa.

"For the first time, the pharmaceutical industry will have to justify to South Africa and to the world why their drug prices are so high and why their patents should be so aggressively protected, when millions of people are dying and cheaper drugs exist," said Zackie Achmat, chairperson of the Treatment Action Campaign.

This follows a week of worldwide demonstrations in support of the South African government, and calling on companies to drop the case. Thousands of people from unions, churches, NGOs and people living with HIV/AIDS took to the streets in Pretoria, Cape Town, and Durban' (Authors' emphasis. TAC, 2001).

An example from the imatinib mesylate dispute is that on February 22, 2012 (on the eve of a Novartis board meeting) activists across the world responded to an MSF call for a global day of action. Act Up-Basel, Act Up-Paris, the Asia 
Pacific Network of Positive People (APN+), Berne Declaration, Health GAP, International Treatment Preparedness Coalition (ITPC) and Oxfam International released a joint statement on their '48 Hours of Action' of 22-23 February that stated:

'Swiss Multinational Pharmaceutical company Novartis is continuing its tradition of suing developing country governments for their prohealth patent laws. In 1999, Novartis along with other pharmaceutical companies sued the South African government over pro-health amendments in their patent law.

Since 2006, they have been suing the Indian government over the health safeguards (Section 3d) in its patent law. India supplies generic medicines across the developing world and health and PLHIV groups in India have been using Section 3(d) of the Indian law to ensure that key medicines stay off-patent. Novartis did not get a patent in India on a cancer medicine and wants this law (Section 3d) weakened. BUT THIS WILL IMPACT ALL OTHER GENERIC MEDICINES AS WELL' (Act Up-Basel, et al., 2012).

Another example is that while final arguments were being heard by the Indian Supreme Court in 2012, a march in support of the Indian government was organised in Cape Town and attended by activists from TAC, MSF and delegates attending the global People's Health Assembly (coincidentally taking place in Cape Town at the time). Together with MSF South Africa, TAC released a media statement titled "Why does a court case in India matter for South Africa?" The statement was clear on the global implications of the case: "A Novartis victory will not only stymie access to life-saving generic [medicines] across southern Africa, but will also result in a negative precedent for countries facing a high burden of disease like South Africa" (TAC and MSF, 2012).

These and many similar actions show quite clearly how the institutional memory embedded in the Global AIDS Movement and the 'repertoires of action' that had developed over more than a decade of global AIDS treatment activism (and even the earlier activism of Act Up and similar groups in the 1980s and 1990s) were explicitly drawn on during the global campaign against Novartis's challenge to Section 3(d). 


\section{The vulnerability of the global medicines access movement}

A notable aspect of the social mobilisation around the imatinib mesylate dispute is the extent to which it was sustained amidst challenging conditions.

For example, a rupture occurred within the access to medicines movement regarding voluntary licenses negotiated by the Medicines Patent Pool. There was significant disagreement among activists over whether to 'compromise' by negotiating with pharmaceutical companies as a pragmatic way to ensure access to medicines in regions and countries with critical needs or whether to 'hold out' and seek a renegotiation of the global intellectual property rights regime. ${ }^{37}$ Nevertheless, these disagreements over voluntary licences seem to have had little impact on solidarity regarding the imatinib mesylate case, perhaps because voluntary licences and the patent pool was a sufficiently separate issue that activists were able to set aside their differences in joint recognition of the importance of (and their shared interests in) the imatinib mesylate dispute.

Kajal Bhardwaj notes that it was difficult to sustain activist momentum in the final phase of the dispute, when the Supreme Court was considering mostly the appropriate interpretation of Section 3(d), rather than the constitutionality and TRIPS compliance of 3(d) itself. But she adds: "It did get sustained, because of collective consciousness". ${ }^{38}$

This chimes with previous findings suggesting that the transnational networks constituting the global AIDS movement often enabled ad-hoc and temporary coalitions constructed when the claims and interests of particular actors converged. Pre-existing networks (with varying levels of density, and strength of links) enabled the quick construction of these ad-hoc coalitions that were not dependent upon full alignment of purpose or long-term alliances. It was characteristic of this movement that more and less radical actors often cooperated on some issues but diverged on others (see Grebe, 2011; 2012a).

This 'collective consciousness' was probably stronger among actors that formed part of longer-term networks and coalitions and manifested in remarkable ways. (This 'collective consciousness' can be thought of as a strong form of what we earlier described in terms of collective action, or simply acting in line with common interests, aimed at contributing to the emergence of 'moral

\footnotetext{
${ }^{37}$ Interviews, Anand Grover (24/06/2014); Kajal Bhardwaj (26/06/2014).

${ }^{38}$ Interview, Kajal Bhardwaj (26/06/2014).
} 
consensus'.) An example is the march in Cape Town described in the previous section.

But, despite the significance of the victory, the medicines access movement was not on a strong footing at the end of the imatinib mesylate dispute. The broader medicines access movement (beyond AIDS drugs) is in some senses in its infancy, relatively small and under resourced. Apart from the imatinib mesylate dispute, it has had few high profile victories outside of antiretrovirals. Historical conditions have changed and become less favourable to medicines access activism. Anand Grover says, "We are on a weaker footing than we were on with HIV and it will be an uphill task [from now on]..."39

Funding for activism on medicines access has been drying up, and institutional memory is being lost. James Loves says. "A turning point was 2007." Four foundations were funding work on intellectual property rights. "We thought it was so easy to raise money." He sees the agreement on the World Intellectual Property Organisation's Development Agenda in 2007 as a turning point. The Development Agenda was supposed to bring greater balance to a historically very-pro-IPR institution. Within 24 months, three of the four main foundations funding civil society activism on IP issues (the MacArthur, Rockefeller and Ford foundations) had stopped doing so. ${ }^{40}$ Grover further says, "After the Gleevec case some of our people left .... to preserve that memory institutionally is a very big challenge." 41

One of the resources the AIDS movement and (the smaller) broader medicines access movement provided, was an inter-connected community of technical experts. But, this technical expertise is concentrated in a relatively small community of professional IPR activists and activist lawyers (in organisations like the Lawyers Collective, KEI, MSF, TAC, SECTION27 and a few others). The recent and continuing decline of the global AIDS movement (see Grebe, 2012b) and the concentration of this expertise, renders the continuing availability of this resource vulnerable.

Pharmaceutical companies have further been adapting their tactics, ${ }^{42}$ Northern governments have also been using Free Trade Agreements to impose 'TRIPS+' provisions on weaker Southern states, resulting in a further strengthening of pharmaceutical IPR protection. Unless the remnants of the transnational activist network can successfully adapt to these changed circumstances, including by tactical and strategic adaptation, attracting significant financial resources and

\footnotetext{
${ }^{39}$ Interview, Anand Grover (24/06/2014).

${ }^{40}$ Interview, James Love (26/06/2014).

${ }^{41}$ Interview, Anand Grover (24/06/2014).

${ }^{42}$ Interview, James Love (26/06/2014).
} 
rebuilding a moral consensus, movements like that which emerged around the imatinib mesylate dispute appear less likely to succeed in future.

\section{Conclusion}

The historic conditions in which the global AIDS movement arose, had several fortuitous elements that made its success possible. For example, the characteristics of HIV/AIDS itself are unusual (patients survive and can be politically active for relatively long periods, even without treatment). AIDS was first recognised in the politicised North American gay community, which allowed a politically astute and radical activist movement to emerge almost immediately (see Epstein, 1998; Smith and Siplon, 2006). The South African epidemic exploded shortly after democratisation, providing unique opportunities for human rights-based activism. Further, an Indian generics industry existed, which provided the material circumstances in which the global AIDS treatment access movement could achieve substantial successes. Similar historical conditions do not exist for the fledgling broader medicines access movement: the international trade and IPR regimes are being strengthened in ways that may make similar battles more difficult in future (for example through bilateral and multilateral Free Trade Agreements outside the WTO that contain 'TRIPS+ provisions'). Thus, as argued in the previous section, the victory represented by the imatinib mesylate case itself and subsequent progress in the development of a strong broader medicines access movement (beyond AIDS drugs) remains under threat.

As we have attempted to show in this paper, the relatively successful global AIDS treatment access movement provided resources, including 'transnational networks of influence', 'repertoires of action', repositories of expertise (particularly technical expertise on IPR law and pharmaceutical research and development), institutional memory and 'bodies on the ground'. The movement that emerged around the imatinib mesylate dispute drew on these resources and exploited existing AIDS-focused networks around a new medicines access issue. This was likely critical to its success. Like the AIDS movement, it also relied on individual agency (many examples could be cited, but Grover and Sapru are significant) and the 'politics of moral consensus' to overcome Novartis's substantial public relations campaign, the tacit support of some Northern governments and the resources Novartis could pour into its legal struggle. One should acknowledge, however, that the 'moral consensus' that emerged over the injustice of patented drugs priced outside the reach of poor patients (and their governments) was not purely the product of activism. An argument that seems to have resonated widely, including in institutions like the WHO and among journalists at influential newspapers etc.-representing what we call a 'moral 
consensus'-also became a 'resource' that the social movement exploited in addition to being produced by its actions.

The imatinib mesylate dispute represents a rare example of mainly Southern civil society groupings (albeit with significant resources channelled via MSF, a prominent Northern NGO, and drawing on Northern expertise such as that in KEI) managing to neutralise the influence and power of a multinational corporation. It can be seen as a case of both South-South and South-North activist and 'influence' networks constructing and drawing on a 'moral consensus' - resulting in a victory of a transnational social movement over multinational corporate power. This kind of victory is rare. The resources, including existing networks and institutional memory, of the AIDS movement was a critical factor in making this victory possible. 


\section{References}

Abbott, F.M. \& J.H. Reichmann. 2007. "The Doha Round's Public Health Legacy: Strategies for the Production and Diffusion of Patented Medicines under the Amended TRIPS Provisions" Journal of International Economic Law. 10(4): 921-987.

Act Up-Basel, Act Up-Paris, Asia Pacific Network of Positive People (APN+), Berne Declaration, Health GAP, International Treatment Preparedness Coalition (ITPC) \& Oxfam International. 2012. Novartis sues Indian Government over health safeguards in Indian Patent Law: 48 HOURS OF ACTION // 22-23 FEBRUARY 2012. Available at:

http://www.actupparis.org/spip.php?article4766 [Retrieved 20 December 2014].

Base21. 2002. Glivec - a wonder drug only for the rich (Jinbo Progress \#2). Base21 News Desk. Available at:

http://base21.jinbo.net/show/show.php?p_cd=0\&p_dv=0\&p_docnbr=20330. [Retrieved: 3 October 2014]

Diani, M. \& D. McAdam. (eds.). 2003. Social Movements and Networks: Relational Approaches to Collective Action. Oxford: Oxford University Press.

Druker, P. 2007. Don't abuse patents: scientists. LiveMint, August 15. Available at: http://www.livemint.com/Opinion/26rbSkGiTxNYKobbO568kL/Don8217tabuse-patents-scientists.html [Retrieved 11 October 2014].

Epstein, S. 1996. Impure Science: AIDS, Activism, and the Politics of Knowledge. University of California Press.

Forman, L. 2008. "Rights" and wrongs: what utility for the right to health in reforming trade rules on medicines? Health and Human Rights, 10(2): 37-52.

Grebe, E. 2008. Networks of influence: a theoretical review and proposed approach to AIDS treatment activism. CSSR Working Paper No. 218. Cape Town: AIDS and Society Research Unit, Centre for Social Science Research, University of Cape Town. Available at:

http://cssr.uct.ac.za/pub/wp/218

Grebe, E. 2009. Contingency, contestation and hegemony: the possibility of a non-essentialist politics for the left. Philosophy and Social Criticism, 35(5): 589611. 
Grebe, E. 2011. The Treatment Action Campaign's Struggle for AIDS Treatment in South Africa: Coalition-building Through Networks. Journal of Southern African Studies, 37(4): 849-868.

Grebe, E. 2012a. Civil Society Leadership in the Struggle for AIDS Treatment in South Africa and Uganda. Doctoral dissertation, University of Cape Town.

Grebe, E. 2012b. 'Global advocacy in an era of resource constraints and shifting global priorities.' Bulletin of Medicus Mundi Switzerland, 125, September 2012. Available at:

http://www.medicusmundi.ch/mms/services/bulletin/hiv-aids-und-advocacy/hivaids-and-advocacy/global-advocacy-in-an-era-of-resource-constraints.html

Grebe, E. 2014. Civil society and the state in Uganda's AIDS response. CSSR Working Paper No. 341. Cape Town: AIDS and Society Research Unit, Centre for Social Science Research, University of Cape Town. Available at http://cssr.uct.ac.za/pub/wp/341.

Grebe, E. 2014b, forthcoming. Understanding the impact of civil society mobilisation on 'AIDS leadership' and HIV outcomes in Africa: methodological challenges and evidence from cross-country regression analysis. Under review. Pre-review version available from the author upon request.

't Hoen, E., Berger, J., Calmy, A. \& S. Moon. 2011. Driving a decade of change: HIV/AIDS, patents and access to medicines for all. Journal of the International AIDS Society, 14(15).

India. 2005. Patents (Amendment) Act, 2005 (Act No. 15). World Intellectual Property Organisation [Online]. Available at: http://www.wipo.int/wipolex/en/details.jsp?id=2407 [Retrieved 25/07/2014].

IPLeft. 2003. The Ministry of Health and Welfare should void the retail price of 23,045 won per pill and stop benefiting the patent right of the drug companies only! Korean Progressive Network, Jinbonet. Available at: http://base21.jinbo.net/show/show.php?p_cd=0\&p_dv=0\&p_docnbr=26759 [Retrieved: 3 October 2014].

Kapstein, E.B. \& J.W. Busby. 2013. AIDS Drugs for All: Social Movements and Market Transformations [Kindle version]. New York, NY: Cambridge University Press.

Keck, M.E. \& K. Sikkink. 1998. Activists Beyond Borders: Activist Networks in International Politics. New York, NY: Cornell University Press. 
KEI. 2014. CPTech's 2003 reports for the RSA Competition Commission, in Hazel Tau et al.v GSK, Boehringer, et al. Washington. Available at: http://www.keionline.org/node/2074 [Retrieved 20 December 2014].

Kerry, V.B. \& K. Lee. 2007. TRIPS, the Doha declaration and paragraph 6 decision: what are the remaining steps for protecting access to medicines? Globalization and Health, 3(3). doi:10.1186/1744-8603-3-3.

Kim, J.Y. 2004. Letter from Jim Yong Kim, HIV/AIDS Director of the World Health Organisation to Dr. A Ramadoss, Minister of Health and Family Welfare of India, 17 December. Available at: http://www.cptech.org/ip/health/c/india/who12172004.html [Retrieved 25/07/2014].

MSF. 2012. Timeline of Key Events in Novartis's attack on the pharmacy of the developing world, 31 January. Available at:

https://www.msf.org.za/msf-publications/timeline-key-events-novartiss-attackon-pharmacy-developing-world [Retrieved 20 December 2014]

MSF. 2014. Untangling the Web of Antiretroviral Price Reductions: $17^{\text {th }}$ Edition, July. Available at:

http://www.msfaccess.org/sites/default/files/MSF_UTW_17th_Edition_4_b.pdf [Retrieved 18 December 2014].

McAdam, D, McCarthy, J.D. \& M. Zald. 1996. 'Introduction: Opportunities, Mobilizing Structures, and Framing Processes-Toward a Synthetic, Comparative Perspective on Social Movements'. In McAdam, D., McCarthy, J.D. and M. Zald (eds.) Comparative Perspectives on Social Movements. Cambridge: Cambridge University Press.

Mrazek, M. F. 2002. Pharmaceutical pricing in the developing world: issues of access to medicines. Expert Review of Pharmacoeconomics \& Outcomes Research, 2(1): 43-50.

Nattrass, N. 2008. The (Political) Economics of Antiretroviral Treatment in Developing Countries. Trends in Microbiology, 16(12): 574-578.

Nattrass, N. 2014. Millennium Development Goal 6: AIDS and the International Health Agenda. Journal of Human Development and Capabilities, 15(2-3): 232246.

Novartis. 2013. Annual Report. Available at: 
http://www.novartis.com/downloads/investors/reports/novartis-annual-report2013-en.pdf

Nunn, A., Da Fonseca, E. \& S. Guskin. 2009. Changing global essential medicines norms to improve access to AIDS treatment: Lessons from Brazil. Global Public Health, 4(2): 131-149.

NYT. 2013. Editorial: India's Novartis Decision. New York Times. April 4. Available at: http://www.nytimes.com/2013/04/05/opinion/the-supreme-courtin-india-clarifies-law-in-novartis-decision.html? $\mathrm{r}=0$ [Retrieved 9 October 2014].

Olesen, T. 2014. Social Movements and Transnationality: A Conceptual Discussion. Paper presented at XVIII ISA World Congress of Sociology, Yokohama, Japan, 18 July.

People's Health Coalition for Equitable Society. 2001. Leukemia Patients are dying because of the outrageously high drug price: Giant Pharma Novartis' greed and South Korean Government's incompetency made this fatal situationSOLIDARITY NEEDED NOW! Available at: http://www.cptech.org/ip/health/gleevec/phces12012001.html [Retrieved: 3 October 2014]

Piot, P. 2012. No Time to Lose: A Life in Pursuit of Deadly Viruses [Kindle version]. New York, NY: W.W. Norton.

SECTION27. 1998. Hazel Tau and Others $v$ GlaxoSmithKline and Others [STATEMENT OF COMPLAINT IN TERMS OF SECTION 49B(2)(b) OF THE COMPETITION ACT 89 OF 1998]. Available at:

http://www.section27.org.za/wpcontent/uploads/2010/10/TauvGSKevidenceAndLegalSubmissions.pdf [Retrieved 20 December 2014].

Shadlen, K. C. 2004. Challenges to treatment: the price-infrastructure trap and access to HIV/AIDS drugs. Journal of International Development, 16(8): 11691180 .

Smith, R.A. \& P.D. Siplon. 2006. Drugs Into Bodies: Global AIDS Treatment Activism. Westport, CT: Praeger.

Smith, R.A., Parker, R.G., Garcia, R. \& R.H. Remien. 2013. 'Social Movement Responses to HIV/AIDS in the United States and Globally: Intersecting Chronological, Strategic, and Health Movement Frames.' In Smith, R.A. (ed.) 
Global HIV/AIDS Politics, Policy, and Activism. Volume 3: Activism and Community Mobilization. Santa Barbara, CA: Praeger.

Taylor, R. 2004. Creating a Better World: Interpreting Global Civil Society. Bloomfield, CT: Kumarian Press.

Tomlinson, C. 2012. Patent law reform will benefit both people with cancer and $H I V$. Quackdown, October 29. Available at:

http://www.quackdown.info/article/cancer-patents/ [Retrieved 20 December 2014].

TAC. 2001. HIGH COURT ACCEPTS THE RIGHT OF PEOPLE WITH HIV TO BE HEARD: National and international organizations welcome the judge's decision. (Joint Press Release by COSATU, TAC, MSF, OXFAM and Consumer Project on Technology, 6 March). Available at: http://www.tac.org.za/newsletter/2001/ns010307.txt [Retrieved 24 December 2014].

TAC and MSF. 2012. Why Does a Court Case in India Matter for South Africa? (Treatment Action Campaign and MSF South Africa joint statement). Available at: http://www.fixthepatentlaws.org/?p=355 [Retrieved 14 October 2014].

UNAIDS. 2013. Global Report: UNAIDS Report on the Global AIDS Epidemic 2013. Geneva: Joint United Nations Programme on HIV/AIDS. Available at: http://www.unaids.org/en/media/unaids/contentassets/documents/epidemiology/ 2013/gr2013/UNAIDS_Global_Report_2013_en.pdf

Waning, B., Diedrichsen, E. \& S. Moon. 2010. A lifeline to treatment: the role of Indian generic manufacturers in supplying antiretroviral medicines to developing countries. Journal of the International AIDS society, 13: 35. doi:10.1186/1758-2652-13-35.

WTO. 1994 Agreement on Trade-Related Aspects of Intellectual Property Rights [The TRIPS Agreement is Annex 1C of the Marrakesh Agreement Establishing the World Trade Organization, signed in Marrakesh, Morocco on 15 April]. Available at:

http://www.wto.org/english/tratop_e/trips_e/t_agm0_e.htm. [Retrieved 20 December 2014].

WTO. 2001. Declaration on the TRIPS agreement and public health. World Trade Organisation, Doha Ministerial 2001, adopted 14 November 2001. Document No. WT/MIN(01)/DEC/2. Available at: 
http://www.wto.org/english/thewto_e/minist_e/min01_e/mindecl_trips_e.htm [Retrieved 25/07/2014].

WTO. 2014. Frequently asked questions about TRIPS [trade-related aspects of intellectual property rights] in the WTO. Available at:

http://www.wto.org/english/tratop_e/trips_e/tripfq_e.htm [Retrieved 21/06/2014]. 